\title{
Subchronic and acute preclinic toxicity and some pharmacological effects of the water extract from leaves of Petiveria alliacea (Phytolaccaceae)
}

\author{
Mildred García-González ${ }^{1,3 *}$, Teresita Coto Morales ${ }^{2,3}$, Rafael Ocampo ${ }^{3}$ \& Liliana Pazos ${ }^{1,2}$. \\ Depto. de Fisiología, Escuela de Medicina. \\ 2 Laboratorio de Ensayos Biológicos, Vicerrectoría de Investigación, Universidad de Costa Rica, San José 2060, \\ Costa Rica. \\ 3 Programa de Investigación científica Aplicada (TRAMIL). \\ * mildredg@cariari.ucr.ac.cr
}

Received 14-VII-2003. C Corrected 19-I-2006. Accepted 11-VIII-2006.

\begin{abstract}
We tested the effects of the aqueous extract of Petiveria alliacea leaves on acute and sub-chronic toxicity, hematocrit and blood glucose level and intestinal motility of male albino NGP mice of 20 to $25 \mathrm{~g}$ mean weight. Treatments were in all cases doses of 1000 and $2000 \mathrm{mg} / \mathrm{kg}$ animal weight and a control treatment with $0.5 \mathrm{ml}$ distilled water, using 10 animals per treatment and administered orally every day (5 days per week). Experimental periods were 18 and 70 days for acute and sub chronic toxicity, respectively. No mortality nor any toxicity signs could be observed. A slight but significant increase in the glucose levels during the first three weeks was observed with the $1000 \mathrm{mg} / \mathrm{kg}$ dose but not for the higher $2000 \mathrm{mg} / \mathrm{kg}$ dose. After administering the doses once after a starving period of six hours, no significant differences in intestinal motility could be found. Rev. Biol. Trop. 54 (4): 1323-1326. Epub 2006 Dec. 15.
\end{abstract}

Key words: Petiveria alliacea, Phytolaccaceae, sub-chronic toxicity, acute toxicity, diabetic intestinal motility, herbal medicine, traditional medicine.

Petiveria alliacea (Gupta 1995) - called commonly ajillo, apacín or zorrillo, is one of the most commonly used medicinal plants in Latin America. It was named after the English botanist Petiver, which described and studied it. The species name alliacea refers to its taste and smell, which is similar to garlic (Alonso 1998). This plant belongs to the family Phytolaccaceae and is endemic to México, Caribbean Islands, Central and Southamerica (Gupta 1995).

It is a perennial herb which can reach one meter in height. The stems are thin and angled, the leaves are elliptic and pointed. The inflorescense is in thin clusters and the fruit is linear (Gupta 1995, Pittier 1978). It grows wild so that it is not cultured. It can be reproduced by seeds and cuttings from shoots or roots, and it prefers shady areas (Bernal and Correa 1998).

This plant is fairly common in pastures of warm climates (Gupta 1995). Its antitumoral effects became known after the "Managua story", which occurred in Nicaragua in 1940. Several leukemic cows which were left on pasture, did not show anymore symptoms of the disease after a time and it was observed that the animals had consumed $P$. alliacea. Several studies upon its effects on cancer and leukemia started upon this finding (Alonso 1998). Upon consumption, the milk of dairy cows acquires the characteristic aroma (Pittier 1978).

In Costa Rica the plant grows wild in both atlantic and pacific slopes, mostly near rivers and under cacao trees, always in the shadow (Ocampo and Maffioli 1987).

In the leaves of $P$. alliacea, the presence of steroids, terpenoids, saponins, polyphenols and tannins has been reported (Segelman and Segelman 1975), further allantoin, potassium nitrate, linoleic acid, lignoceryl alcohol, lignoceryc acid, lignoceryl ester, nonadecanoic 
acid, oleic, palmitic and stearic acids (De Souza et al 1990), glucosids and alkaloids (Roig 1974). The chemical structure of the toxic compound, which has been called petiveriin (Gupta 1995).

This plant has been proposed for a diversity of uses. Decoction of leaves against influenza (García 1998), gastrointestinal affections like diarrhea, dysentery and flatulencies, respiratory diseases like amygdalitis, asthma, bronchitis, catarrh and whooping cough, as tranquilizer and for diabetes (Cáceres 1996). Decoction of the whole plant is recommended in inhalations for sinusitis, asthma, bronchial catarrh and cough and as mouth wash against caries and teeth pain (Ocampo and Maffioli 1987). In Caribbean countries the leaf extracts are frequently used for digestive affections (Robineau 1989). This study presents the effects of an oral administration of the aqueous extract of boiled leafs of $P$. alliacea on albino mice, analyzing the overall toxicity and the effects on the blood glucose and on the intestinal motility.

\section{MATERIALS AND METHODS}

Plants: The plants were collected in September 1995 in the Agroecological Garden for Medicinal Plants TRAMIL in Baltimore, Matina, Limón province in Costa Rica, about 100 meters over sea level. A sample of this material was deposited in the Herbarium of the Biological School of the University of Costa Rica with the reference 77051 USJ.

Aqueous extract: $950 \mathrm{~g}$ of fresh leaves were blended in 41 unionized water and heated to $80^{\circ} \mathrm{C}$ for $30 \mathrm{~min}$ The extract was filtered through medical gauze and yielded $43.36 \mathrm{~g}$ of lyophilized material. With this material an aqueous extract of $100 \mathrm{mg} / \mathrm{ml}$ was prepared.

Acute oral toxicity: Thirty male albino mice from the strain NGP were used with an average weight of $24.13 \pm 0.07 \mathrm{~g}$. The animals were distributed in three groups of 10 mice each for the following 3 treatments: 1000 and
$2000 \mathrm{mg}$ aqueous extract $/ \mathrm{kg}$ animal weight and a control group which received only $0.5 \mathrm{ml}$ distilled water. The extract was administered orally, five consecutive days per week during three weeks.

Sub-chronic oral toxicity: Thirty male albino mice from the strain NGP were used with an average weight of $25.32 \pm 0.31 \mathrm{~g}$. The treatments and administration were the same as for acute toxicity but this experiment had a duration of 8 weeks. Experimental data were measured daily, using the polydimensional array of Irwin (18). The animals were weighed weekly.

Blood glucose: The first blood sample was obtained prior to administering the first aqueous extract. Afterwards the blood samples were obtained weekly for a total of eleven samples. The blood was obtained by puncturing the orbital sinus and filling two heparinized micro capillaries per animal and per sample. Blood glucose concentration was assessed with the glucose oxydase method of Trinder modified by Schosinsky (Schosinsky et al. 1974). The hematocrit value was also measured.

Intestinal motility: Intestinal transit time was measured with the method of CYTED (CYTED 1995) in thirty male NGP mice with an average weight of $22.06 \pm 0.58 \mathrm{~g}$, divided in three groups. The treatments $(1000 \mathrm{mg} / \mathrm{kg}$ and $2000 \mathrm{mg} / \mathrm{kg}$ aqueous extract and $0.5 \mathrm{ml}$ distilled water as control, were administered orally after six hours fasting.

\section{RESULTS}

Toxicity: No mortality nor any signs of toxicity were found at both doses (1 000 and 2 $000 \mathrm{mg} / \mathrm{kg}$ ) during both experimental periods (18 and 70 days). The weight increase of the animals during this period was normal.

Blood analysis: The weekly data of blood glucose and hematocrit were compared with the pre-treatment values and with the control 
group. In the treatment $1000 \mathrm{mg} / \mathrm{kg}$ the blood glucose concentration increased significantly $(\mathrm{p}<0.01)$ during the first three weeks, returned again to normal values and increased again significantly the days $45(\mathrm{p}<0.05), 52$ and 70 $(\mathrm{p}<0.01)$ but finishing the experimental period with normal values. With the treatment 2000 $\mathrm{mg} / \mathrm{kg}$ no significant changes in the blood glucose levels were observed.

The hematocrit decreased significantly by the day $13(\mathrm{p}<0.01)$, increased again by the days $42,45(\mathrm{p}<0.05)$ and $59(\mathrm{p}<0.01)$, finishing the experiment with normal levels.

Intestinal transit: Mean percentage intestinal transit was $53.917 \pm 1.49(1000 \mathrm{mg} / \mathrm{kg})$, $51.167 \pm 3.23(2000 \mathrm{mg} / \mathrm{kg})$ and $53.20 \pm 2.28$ (control), without statistical differences.

\section{DISCUSSION}

The results in the toxicity evaluation support the findings of other authors which did not find any sign of toxicity with orally-administered aqueous extracts of leaves at doses of $10 \mathrm{~g} / \mathrm{kg}$ (Del Carmen et al. 1988) and $5 \mathrm{~g} / \mathrm{kg}$ (Cáceres et al. 1993). A genetic toxicity of leaf aqueous extract on the germ cells of male mice was also excluded (Morón 1995).

However, in sheep consuming daily this plant, a caquexic muscular distrophy developed, caracterized by weakness and ataxy in the hind limbs, dehydration and weight loss, bradycardia and increased levels of transaminases and urea. The necropsy showed muscle atrophy with fragmentation and hyalinization of muscle fibers as well as renal lesions (Nuñez et al 1983).

Other authors have established a $\mathrm{DL}_{50}$ for orally administered leaves in rats at $360 \mathrm{mg} / \mathrm{kg}$ and in mice by intraperitoneal administration at $1.7 \mathrm{~g} / \mathrm{kg}$ (Estevez et al. 1976). Possible mutagenic and carcinogenic effects after very long periods of feeding have been mentioned (Hoyos 1992).

Further studies (Lores and Cires 1990, Morales 1990) have reported a $60 \%$ decrease in blood glucose levels after oral administration of leaf and branch extracts of $P$. alliaceae. These results are not supported by our experiment which showed a transitory, statistically significant increase of blood glucose with the 1 $000 \mathrm{mg} / \mathrm{kg}$ treatment, and no significant effect with the higher dose of $2000 \mathrm{mg} / \mathrm{kg}$.

On the other hand, a positive effect on the contraction of the smooth muscle of aorta, uterus, ileum, trachea and gastric fundus has been described (Morón 1996), so that an abortive effect has been attributed to this plant making it contraindicated in pregnancy.

A pre clinic study of the effects of aqueous and ethanolic leaf extracts on carcinoma in male albino mice was realized in the National Institute for Oncology and Radiology in Cuba. No anti carcinogenic activity could be found on transplant induced sarcoma 180, 37, carcinoma of Ehrlich and adenocarcinoma of the mammary gland (Estevez 1976).

\section{ACKNOWLEDGMENTS}

This investigation was supported by the Vicerrectoría de Investigación of the Universidad de Costa Rica and by the CIID of Canada, through the TRAMIL Program of Central America.

\section{RESUMEN}

Se evaluaron los efectos del estracto acuoso de las hojas de Petiveria alliacea, en la toxicidad aguda y toxicidad subcrónica, hematocritos, niveles de glucosa en la sangre y motilidad intestinal del ratón macho albino NGP, con un peso promedio de 20 a 25g. En todos los casos los tratamientos fueron dosis de 1000 y $2000 \mathrm{mg} / \mathrm{kg}$ de peso del animal y un tratamiento control con $0.5 \mathrm{ml}$ de agua destilada, usando 10 animales por tratamiento y administrado oralmente cinco días por semana. Los períodos experimentales fueron de 18 y 70 días para toxicidad aguda y toxicidad subcrónica, respectivamente. No se observaron signos de mortalidad ni de toxidad en ambas pruebas. Con la dosis de $1000 \mathrm{mg} / \mathrm{kg}$ hubo un leve pero significativo incremento en los niveles de glucosa durante las primeras tres semanas, pero no con la dosis más alta de $2000 \mathrm{mg} /$ $\mathrm{kg}$. Después de administrar las dosis luego de un período de hambre de seis horas, no se encontraron diferencias significativas en la motilidad intestinal. 
Palabras clave: Petiveria alliacea, Phytolaccaceae, toxicidad sub-crónica, toxicidad aguda, motilidad intestinal diabética, hierba medicinal, medicina tradicional.

\section{REFERENCES}

Alonso, J. R. 1998. Tratado de Fitomedicina. Bases clínicas y farmacológicas. ISIS, Buenos Aires, Argentina. $798 \mathrm{p}$.

Bernal, H.Y. \& J.E. Correa. 1998. Especies vegetales promisorias de los países del Convenio Andrés Bello. SECAB. Santafé de Bogotá, D. C. Colombia. Tomo XII, p. 383-422.

Cáceres, A., L. Fletes \& L. Aguilar. 1993. Plants used in guatemala for the treatment of gastrointestinal disorders. Confirmation of activity against enterobacteria of 16 plants. J. Ethopharmacol. 28: 31-38.

Cáceres, A. 1996. Plantas de uso medicinal en Guatemala. Editorial Universitaria. Universidad de San Carlos, Guatemala. 402 p.

CYTED. 1995. Manual de Técnicas de Investigación. Subprograma X. Química Fina Farmaceútica. Proyecto X-1. Búsqueda de Principios Bioactivos en Plantas de la Región. Madrid, España, p. 151-153.

De Souza, J.R., A.J. Demuner, J.A. Pinheiro, E. Breitmaier \& B.K. Cassels. 1990. Dibenzyl trisulphide and transn-methyl-4-methoxyproline from Petiveria alliaceae. Phytochemistry 29: 3653-3655.

Del Carmen, R. 1988. Actividad anti-inflamatoria y analgésica de Petiveria alliacea. MINSAP/enda-caribe. Farmacopea Caribeña. La Habana, Cuba. 247 p.

Estevez A. 1976. Resultados de la actividad antitumoral y tóxica del principio activo de la Pettiveria alliacea Linn. Rev. Cub. Farm 10: 81-84

Feraz, M.B., R.B. Pereira, N.M., Iwata, \& E. Atra. 1991. Tipi a popular analgesic tea: a double bind cross over trial in ostearthritis. Clin. Exp. Rheumatol. 9: 205-206.

Furones, J.A, F.Morón, \& G.Z. Pinedo.1996. Ausencia de actividad antiinflamatoria del extracto acuoso liofilizado de Petiveria alliacea (anamú) en ratas. Rev. Cub. Plant. Med. 1: 34-37.

Furones, J.A, F. Morón, \& G.Z. Pinedo.1996. Ausencia de la acción analgésica de la Petiveria alliacea (anamú) en ratones. Rev. Cub. Plant. Med. 1: 16-18.
García, S.A. 1998. Plantas de la medicina Bribrí. Universidad de Costa Rica. San José, Costa Rica. 48 p.

Gupta, M.P. (Ed.) 1995. 270 Plantas medicinales Iberoamericanas. CYTED-SECAB. Santafé de Bogotá, Colombia. 434 p.

Hoyos, L. 1992. Evaluation of the genotoxic effects of a folk medicine, Petiveria alliacea. Mutat. Res. 280: 29-34.

Lores, R. \& M. Cires Pujol. 1990. Petiveria alliacea. Study of the hypoglycemic effect. Med. Interne. 28: 347-352.

Morales, A.S. 1990. Inhibición in vitro de Trichomonas vaginalis por extractos acuosos vegetales de uso popular. Tesis de grado, Fac. CCQQ y Far, USAC, Universidad de San Carlos, Guatemala. 89 p.

Morón, F. 1995. Actividad toxicológica de los extractos de Petiveria alliacea. Hacia una Farmacopea Caribeña. Universidad Nacional Autónoma de Honduras, Tegucigalpa, Honduras. 478 p.

Morón, F. 1996. Actividades farmacológicas del extracto acuoso de las hojas de Petiveria alliacea. Farmacopea Caribeña. Universidad Nacional Autónoma de Honduras, Tegucigalpa, Honduras. 247 p.

Núñez, B.V., D.L. Venegas \& G.J. Torres. 1983. Caquexia muscular distrófica y su relación clínico-patológica con neurotoxicidad retardada. Rev. ICA. 28: 345-353.

Ocampo, R.A. \& A. Maffioli. 1987. El uso de algunas plantas medicinales en Costa Rica. Vol. 1. San José, Costa Rica. 16 p.

Pittier, H. 1978. Plantas usuales de Costa Rica. Editorial Costa Rica. San José, Costa Rica. p. 71 p.

Robineau, L. 1989. Hacia una Farmacopea Caribeña. Universidad Nacional Autónoma de Honduras, Tegucigalpa, Honduras. 472 p.

Roig, J.T. 1974. Plantas medicinales, aromáticas o venenosas de Cuba. Ciencia y Técnica. Instituto del Libro, La Habana, Cuba. 158 p.

Schosinsky, K. H., H. P. Lehmann \& M. G. Beeler. 1974. Measurement of ceruloplasmin from its oxidase activity in serum by use of o-dianisidine dihydrochloride. Clin. Chem. 20: 1556-1563.

Segelman, F.P \& A.B. Segelman, 1975. Constituents of Petiveria alliacea L. (Phytoloccaceae), Part I. Isolation of isoarborinol, isoarborinol acetate and isoarborinol cinnamate for the leaves. Lloydia 38: 537. 